LINGUA, Vol. 16, No. 2, September 2019

p ISSN: 1979 9411; e ISSN: 2442 238X

Http://lingua.soloclcs.org; Email: presslingua@gmail.com

Center of Language and Cultural Studies, Surakarta, Indonesia

Kolobe, 'Maboleba \& Thetso, 'Madira. 2019. Language use by tertiary students:

The case of the National University of Lesotho.

Lingua (2019), 16(2): 157-174. Http://doi.org/10.30957/lingua.v16i2.265.

\title{
Language use by tertiary students: The case of the National University of Lesotho
}

\author{
Dr. 'Maboleba Kolobe \& Dr.' Madira Thetso \\ National University of Lesotho \\ P.O. Roma 180, Roma \\ Email: mb.kolobe@gmail.com \& thetsoleonia@gmail.com
}

\begin{abstract}
This study interrogates the use of language by students at tertiary. It focuses on students' interactions with one another outside classroom setting. The study hypothesizes that the language used by university students display richness and yet complexity of human language. In focus groups, third year students were requested to give words which according to them have acquired new meanings on campus as compared to their common use anywhere else. Thus, such words should be believed to have their 'campus' meaning versus their 'home' meaning on the basis that their campus meanings might only be understood amongst university students while at the same time would be given a different meaning when used outside the university. Content analysis was done drawing on the underpinnings of communicative competence and componential theory of creativity frameworks. Data yielded significant patterns of language use including polysemy, among tertiary students; therefore, the study concludes that students' exploitation of language is attributive of their communicative competence and creativity.
\end{abstract}

Keywords: Communication, Language creativity, Communicative competence, Componential theory of creativity.

\section{INTRODUCTION}

Even though communication as a discipline has attracted a lot of research on sectors including family-settings (Harvey \& Ahmann, 2016; Chan, 2017); health settings (King, Porr \& Gaudine, 2017; Roze Des Ordons et al., 2017) just to mention a few, research on communication and students' social interaction dimension has not been much of interest to researchers. Previous research that attempted to bring into picture communication and students' social aspect (Mahmud, 2013) is limited in that it only focused on the literary implications brought by communication competence. For instance, Mahmud's study specifically interrogated the impact of communication skills on students' academic performance (see Godfinch \& Hughes, 2007; Yahaya \& Ramli, 2009; McCroskey et al., 1989; Zimmerman, 2000). Thus, these researches still left unexploited the impact of the communication skills outside classroom settings where students use language unconstrained to interact on matters concerning their everyday 
LINGUA, Vol. 16, No. 2, September 2019

p ISSN: 1979 9411; e ISSN: 2442 238X

Http://lingua.soloclcs.org; Email: presslingua@gmail.com

Center of Language and Cultural Studies, Surakarta, Indonesia

Kolobe, 'Maboleba \& Thetso, 'Madira. 2019. Language use by tertiary students:

The case of the National University of Lesotho.

Lingua (2019), 16(2): 157-174. Http://doi.org/10.30957/lingua.v16i2.265.

life. The gap makes this study a necessary fill-up in the communication studies and becomes a lead to possible research for future.

\section{REVIEW OF LITERATURE}

Language is not only used for communication but communication itself is one of the major uses of language. Put simply, language expedites communication and is essential for the communication of complex content. Communication in turn is vital for the coordination of interactions in groups or teams such as student groups. Cleary (2001: v) submits that the term 'communication' originates from a Latin word 'communicare,' meaning to make common. Communication is used, among other things, to convey information and understanding of that information from one person (sender) to another person (receiver). Summatively, communication is said to be a process that involves several components including the sender who first encodes a message and transmits it through an appropriate channel to the receiver who decodes itand gives feedback (Adler, Rosenfeld \& Proctor, 2010). It is through this process that participants should experience common understanding of one another to ensure effectiveness of communication. However, understanding is guaranteed when participants have a common knowledge not only on the shared information but also on the meaning of the shared information. The quality of students' understanding rests on their ability to master and use bodies of knowledge that are valued by their culture. In the context of this study, students should be able to understand the humanly constructed nature of this knowledge and to draw on it to interact as they wish, for instance, to express their diverse emotions, to seek assistance from fellow students and so on. In fact, students should be able to use this knowledge to engage in effective communication. Effective communication, therefore, occurs when the intended message of the sender and the interpreted message of the receiver are one and the same.

In order for participants to understand one another, the initiator and/or sender of the communication should first know what to say, how to say it, to whom and the right time to say it. With these considerations, one can guarantee reaction to their initiation. Mkanganwi (2008:12) postulates that "Effective dissemination of information...is highly dependent on the ability to understand the language that is being used". In the same vein, Cannon-Bowers (1993) and Clark (1996) echo the need for this understanding by bringing into picture the concept of 'common ground'. They state that communicating effectively results from participants' common ground or common agenda. This is a situation where each member of the group has a philosophy of the mind of the other member which will also appreciate the fact that others have a philosophy of the mind of oneself. The point we are trying to make here is that all members in a group should at least share some common understanding of one another. In this way, communication would have been used to enable the instituting, maintenance and adjustment of such shared expectations about each other's minds as stated by Cannon-Bowers and Clark (op.cit.).

Common ground is understood to be the prime basis that assists in unifying the actions of a group. Common ground does not only embrace factual claims made by 
LINGUA, Vol. 16, No. 2, September 2019

p ISSN: 1979 9411; e ISSN: 2442 238X

Http://lingua.soloclcs.org; Email: presslingua@gmail.com

Center of Language and Cultural Studies, Surakarta, Indonesia

Kolobe, 'Maboleba \& Thetso, 'Madira. 2019. Language use by tertiary students:

The case of the National University of Lesotho.

Lingua (2019), 16(2): 157-174. Http://doi.org/10.30957/lingua.v16i2.265.

participants during interactions but also feature common goals and objectives that the participants setout to achieve by the interactions they engage in. It comprises huge background knowledge that is supposed to be shared by the group by virtue of their membership to a language community. In the process of communication, lack of common ground can be easily detected when miscommunication occurs and in such a state, participants are expected to save the situation. They may either repeat themselves or substitute some of the contents in their utterances to ensure that they are heard and understood. This is easily achieved if participants share one language and one culture. Samova \& Porter (2001) state that language is regarded as the key to the heart of a culture, so, if participants belong to one culture, they would surely understand one another's language, hence, this study focuses on students' use of language in their own language community. For the purposes of this study, students are supposedly a group sharing one culture during their studentship. The section below outlines general purposes of communication which inform the context from which students may use language.

\subsection{Purposes of communication}

Communication is used to carry out various practical tasks (Wiemann, 1997) such as consoling a friend who has failed an exam or negotiating one's late coming to class or a make-up test to upgrade chances of proceeding to the next year. It is also used as a tool for promotion of functional and effective human living and interaction. "Without communication, it would be impossible to relate to others around you... communication is therefore an endeavor to reach the minds of others" (Cleary 2001:v). In support of Cleary's declaration, Huebsch (1995) affirms that no living things can exist with a purpose on earth if they lack tools of communication. He mentions that if these tools are lacking, the necessary understanding, insight, empathy, knowledge and general understanding would be impossible. In other words, when one utters an expression, the ultimate goal is to create a common understanding with the other person because human beings are gregarious. Furthermore, communication is used for and according to the needs of society one lives in hence changes in meaning and interpretation of language items used.

In the same vein, Pearson et al. (2003:23) mention that communication takes place within sets of circumstances or situations they refer to as 'communication contexts'. These contexts include communication that occurs within oneself (intrapersonal communication), between two or more people (interpersonal communication) or between cultures (intercultural communication). In any of the contexts, the participants' goal is to effectively convey meaning, using a common system of symbols, signs or behaviour. The same observation is reiterated by Palma (2013) that speaker's ability to speak a language correctly is not demonstrated only by displaying knowledge of vocabulary and grammar, but also the context in which words are used.

Effective communication is further viewed in light of the following three interconnected, yet separate dimensions: superficial, attitudinal and intentional 
LINGUA, Vol. 16, No. 2, September 2019

p ISSN: 1979 9411; e ISSN: 2442 238X

Http://lingua.soloclcs.org; Email: presslingua@gmail.com

Center of Language and Cultural Studies, Surakarta, Indonesia

Kolobe, 'Maboleba \& Thetso, 'Madira. 2019. Language use by tertiary students:

The case of the National University of Lesotho.

Lingua (2019), 16(2): 157-174. Http://doi.org/10.30957/lingua.v16i2.265.

dimensions. The first dimension involves getting the message across. The message is constructed in a clear and straight forward manner to convey all pertinent information.

In the second dimension, participants identify one another's attitudes that clarify the meaning of the spoken words. This dimension attaches the emotional association of the message hence the message would now have structural and attitudinal implications. The third dimension is concerned with intentionality. Participants reflect of the message on whether the purpose behind such communication has been achieved. The three dimensions can be translated into the following communication characteristics which the researchers think form the basis that inform the discussion of the data collected from the National University of Lesotho students:

- Communication is purposeful

- Communication provokes the interest of the participants into powerful engagement

- Communication maintains the interest of the participants so much that they may ensure continuity of the interaction by contributing actively

- Communication brings in new knowledge to the participants

- Communication encourages participants' respect for one another's differences hence participants interact non-judgmentally

- Communication is appropriately-set

\subsection{Theoretical framework}

The study is based on the underpinnings of communicative competence theory (Brateen, 1991) and componential theory of creativity (Amabile, 1983). The approaches accommodate the view that competence is recognised in observing communicators' performance, presumably, because the kind of expressions, whether the words themselves or their make-up into any type of communicative utterance one uses to interact with the world around them, is reflective of their competence in communication and/or language, 'A reconstruction of communicative competence may be held as adequate if it ...is capable of accounting for all observed patterns in the ...usage of sentences...to generate entailments that agree with speakers' intuitions' (Brateen, 1991:59) since communication occurs to accomplish a goal, 'good or ill' (Greene \& Burleson, 2008:291). On account of this competency, communicators enjoy the liberty to manipulate the language to suit their goals. On the same vein, university students have their own way of using language to fulfill their intentions, good or ill. Intrigued by this observation, the researchers explore the nature of the language the students employ in their everyday interactions with one another. Therefore, in the context of this study, the theory specifically guides the scope of data collected and its analysis. The different expressions uttered by students are accommodated within the competence areas of linguistic, sociolinguistic, discourse, and strategic of this theory as outlined by Hymes (1993) and Johnson \& Johnson (1998).

First, linguistic competence addresses participants' knowledge on how to use the grammar, syntax, and vocabulary of a language. They usually have to make a choice on which words to use and how to construct them into comprehensible chunks. 
LINGUA, Vol. 16, No. 2, September 2019

p ISSN: 1979 9411; e ISSN: 2442 238X

Http://lingua.soloclcs.org; Email: presslingua@gmail.com

Center of Language and Cultural Studies, Surakarta, Indonesia

Kolobe, 'Maboleba \& Thetso, 'Madira. 2019. Language use by tertiary students:

The case of the National University of Lesotho.

Lingua (2019), 16(2): 157-174. Http://doi.org/10.30957/lingua.v16i2.265.

Second, sociolinguistic competence refers to a situation whereby participants adhere to correct approach to use language and to respond appropriately, given the setting, the topic, and the relationships among the people engaged in communication. Third, discourse competence addresses interpretation of larger context and how to construct longer stretches of words, phrases and sentences so that they result in a coherent whole.

The fourth competence is strategic competence. This kind expresses the ability to recognize and repair communication breakdowns. It enables the communicators to work around gaps in one's knowledge of the language, and to learn more about that language and the context in which it may appropriately be used. It is with possession of this competence that communicators would know when they have misunderstood someone or when they have been misunderstood and then the appropriate strategy to apply to correct the miscommunication. The current study seems to draw much on both sociolinguistic and strategic competencies than it does with the other two competencies.

Similarly, Hymes cited in Bachman (1990) unpacks communicative competence into 16 components that can be used across discourses inclusive of students' discourse. Such are message form, message content, setting, scene, speaker/sender, addressor, hearer/receiver/audience, addressee, purposes (outcomes), purposes (goals), key, channel, forms of speech, norms of interaction, norms of interpretation and genres. These components relate to this study in more ways than one. Since the study aims at investigating the language used by students at tertiary in their daily interactions, its focus in on message form and message content mentioned by Bachman. It further recounts to the intention of the addressor and the norms of interaction that they share with the hearer/receiver/audience. The researchers in this study are aware of the different meanings depicted on the words the students use as compared to how the same words are used outside the confines of the campus, hence the setting, scene, purposes, forms of speech, norms of interpretation and genres are significant variables of this study. Lane (2000) also emphasizes that communicative competence is measured by how and to what degree the goals of interactions are achieved

\section{METHODOLOGY}

Crabtree \& Miller (1992) emphasize the significance of illustrating the research approach in order to increase the validity of social research. The present study adopted a qualitative research approach. It investigated the social phenomenon of language use by students at tertiary. When showing merits of this kind of research, Altheide (1996) explains that qualitative research aims to gather an in-depth understanding of human behaviour and the reasons that govern such behaviour. The qualitative aspect of this study manifests itself on the in-depth examination of patterns of language used by students and how this language manifests various meanings. Yin (2009:19) adds that "colloquially a research design is an action plan for getting from 'here' to 'there', where the 'here' may be defined as the initial set of questions to be answered and 'there' is some set of (conclusions) answers." This study examined a human decision over the use of certain words for a special purpose of communication. It coupled this 
LINGUA, Vol. 16, No. 2, September 2019

p ISSN: 1979 9411; e ISSN: 2442 238X

Http://lingua.soloclcs.org; Email: presslingua@gmail.com

Center of Language and Cultural Studies, Surakarta, Indonesia

Kolobe, 'Maboleba \& Thetso, 'Madira. 2019. Language use by tertiary students:

The case of the National University of Lesotho.

Lingua (2019), 16(2): 157-174. Http://doi.org/10.30957/lingua.v16i2.265.

approach with a case study strategy as Stake (1995) recommends that the most typical application of qualitative research seems to be that of case studies.

Case studies are defined in various ways; however, a general definition compiled from a number of sources such as Stake (1995), Altheide (1996), Yin (2009) and Meyer (2001) is that a case study examines a phenomenon in its natural setting, employing multiple methods of data collection to gather information from one or a few entities. Gillham (2000:1) adds that a case study is an investigation to answer specific research questions which seek a range of different evidence from the case settings. In the same vein, Yin (2009:13) explains that case studies may be used as a method of inquiry. He states that they are conducted within a defined time frame. This particular study drew data specifically from the National University of Lesotho third year students.

There are some criticisms that case study strategy lacks representativeness and statistical generalis ability (Gillham, 2000). However, Yin (2009) argues that a case study strategy may be used to establish general concepts. He states that case studies are used for analytical generalizations, where the researcher's aim is to generalize a particular set of results to some broader theoretical propositions. Indeed the present study investigates students' use of language at tertiary in a manageable case of one, yet main university in Lesotho, that would be able to serve as a reference for further research related to this one. Generally, it is argued that case study strategy lays a platform for the research to be conducted in an area where few, if any, previous studies have been undertaken as is the case with this one. This kind of study enhances effective descriptions of the data possible and allows for direct and credible reflections on the views of the participants (Chan, 2017; Sandelowski, 2010).

Data collected for this study were guided by the following questions:

a) What are the messages shared amongst students at tertiary institutions?

b) What communication patterns surface in students' use of language at tertiary institutions?

Data were collected from third year students majoring in English and African Languages at the National University of Lesotho in the Faculty of Humanities. This scope was for the purposes of convenience as it proved convenient to organize focus group discussions with students in the researchers' classes. Participants were informed of the academic purpose of the study and that they have a right to keep quiet or withdraw from the discussions if they so wish.

The researchers asked the participants in their classes to provide words that according to them have acquired new meanings on campus (campus meaning) but have different meanings or are understood differently when used outside the confines of the university (home meaning). Such words were recorded together with their campus meanings and home meanings provided by the students as data for this study. For purposes of consistency, the expressions campus meaning and home meaning are used throughout the paper to differentiate the different meanings the words and/or expressions have acquired. 
LINGUA, Vol. 16, No. 2, September 2019

p ISSN: 1979 9411; e ISSN: 2442 238X

Http://lingua.soloclcs.org; Email: presslingua@gmail.com

Center of Language and Cultural Studies, Surakarta, Indonesia

Kolobe, 'Maboleba \& Thetso, 'Madira. 2019. Language use by tertiary students:

The case of the National University of Lesotho.

Lingua (2019), 16(2): 157-174. Http://doi.org/10.30957/lingua.v16i2.265.

Fundamentally, as the aim of this study was to interrogate the use of language by students at tertiary in order to examine the richness and creativity of students in language use, the study adopted and adapted a summative content analysis technique. The technique involves counting and comparisons of text keywords or text content followed by the interpretation of the underlying content (Hsieh \& Shannon, 2005). Expressions that students gave were recorded on papers and presented on tables as data for this study. The collected data were categorized according to syntactic structures and/or levels of word-level, phrase-level and sentential-level. Each expression was then presented with its campus meaning and home meaning as taken from the participants. After that the campus meanings were critically analysed by discussing the relationship between the two meanings and the referent in question. (The same expressions were presented to two more classes of students in first and second years of study at the University for purposes of validity of the expressions.) Each table had three columns. The first column listed the collected expressions while the second column presented the home meaning of the expression. If the expression was a phrasal, the focus word was bolded for easy identification. The third column presented both the campus meaning and the discussion.

\section{RESULTS AND DISCUSSION}

The relationship between words and meanings is extremely complicated. Research shows that it is much more difficult to pin down the precise meaning of a word or phrase for the very fact that it is still challenging to determine precisely what meaning is in the first place. O'Grady et al. (1996) associate meaning with something that takes place in the mind and that must be more abstract than pictures and that there is more to it than just features hence they talk about connotation and denotation as two principal methods closely related with the concept of meaning. Connotation, on one hand, is explained as a set of associations that a word's use can evoke (emotional or otherwise), a situation whereby a meaning of a word is determined by context in which the word is used. It is understood to represent the various social implications, cultural insinuations, or emotional meanings associated with a word. The connotative meanings of a word exist together with the denotative meanings. Denotation, on the other hand, is related to entities to which a word refers. This notion represents the explicit or referential meaning of a word. Traditionally, grammarians refer to denotative meaning of a word as a literal meaning of a word or the dictionary definition. The same concepts of meaning have also benefited interpretation of data for this study. Based on the collected data, students' use of language surfaced the following patterns:

\subsection{Polysemous expressions}

Polysemy comes from Greek family to mean 'of many senses'. It is a semantic concept that has attracted various definitions from many authors including Taylor (2006) who defines it as the association of two or more related senses with a single linguistic form. Fillmore \& Atkins (2000) talk of it as the capacity for a word to have multiple meanings. It is also understood as the semantic ambiguity of an individual 
LINGUA, Vol. 16, No. 2, September 2019

p ISSN: 1979 9411; e ISSN: 2442 238X

Http://lingua.soloclcs.org; Email: presslingua@gmail.com

Center of Language and Cultural Studies, Surakarta, Indonesia

Kolobe, 'Maboleba \& Thetso, 'Madira. 2019. Language use by tertiary students:

The case of the National University of Lesotho.

Lingua (2019), 16(2): 157-174. Http://doi.org/10.30957/lingua.v16i2.265.

word or phrase that can be used in different contexts to express two or more different meanings. To talk about polysemy requires one to look at word's etymology hence analysis of this study presents two meanings for each expression: the first one (home meaning) being what is believed to be the literal meaning (as found in a dictionary) and the second one being its campus meaning. Polysemy features much as a feature of ordinary language usage; therefore, people are able to assign intended interpretation on polysemous expression naturally without any effort. For instance, polysemy is again observed in dictionaries where dictionary entries would list different senses under one lemma. The easiness is further realized from a range of non-established senses that expressions are used to refer to on different occasions of use, which are contextually derived on the spot as it is the case in this study.

In modern approach, polysemy is considered the result of the interaction of several factors including linguistic, cognitive and communicative (Falkum, 2011). According to Breal (1924) in Nerlich (2003), polysemy is understood as a diachronic phenomenon emanating as a result of semantic change. It is noted that polysemy furthers acquisition of new meanings of words through use, while at the same time; language users would still embrace the old meanings of such words. Therefore, polysemy should be taken as the result of the parallel existence of new and old meanings in the language, which marks a change of function into synchronic side of lexical semantic change. Research has proven the unproblematic effect of polysemy from the point of view of communication as speakers may exploit the polysemous potential of an expression to create confusion or a humorous effect. It is interestingly observed that participants trust one another to use contextual cues to quickly and reliably figure out the meaning they intend to communicate when using a word that could take on a different meaning in a different context.

Polysemy is realized in three types. First, metaphoric polysemy refers to polysemy instances in which an expression has literal and figurative meanings. Second, specialization polysemy refers to polysemy which denotes a hierarchical relation between the meanings of a polysemous term. In this case, meaning of A may be a more general meaning of a meaning B. Homonymy is the third type of polysemy where contrastive polysemous expressions give birth to unrelated meanings (Evans \& Zinken, 2006). Table 1 presents instances of polysemy in a form of infinitives.

Table 1: Polysemous expressions as infinitives

\begin{tabular}{|c|c|c|}
\hline Expression & $\begin{array}{l}\text { Home } \\
\text { meaning }\end{array}$ & Campus meaning \\
\hline 1 ho etsa sehoapa & To make biltong. & $\begin{array}{l}\text { Clothes that were washed and dried on the spot; } \\
\text { wash and wear clothes } \\
\text { As compared to home meaning of 'sehoapa' the } \\
\text { campus meaning relates to biltong in that the clothes } \\
\text { are also dried by sun in the same way meat is dried in } \\
\text { the sun to make biltong. The difference of the campus } \\
\text { meaning rely on the object that is dried which is } \\
\text { clothes while the home meaning's object is meat. The } \\
\text { word 'sehoapa' is given at least two senses, therefore, } \\
\text { polysemous. }\end{array}$ \\
\hline
\end{tabular}


LINGUA, Vol. 16, No. 2, September 2019

p ISSN: 1979 9411; e ISSN: 2442 238X

Http://lingua.soloclcs.org; Email: presslingua@gmail.com

Center of Language and Cultural Studies, Surakarta, Indonesia

Kolobe, 'Maboleba \& Thetso, 'Madira. 2019. Language use by tertiary students:

The case of the National University of Lesotho.

Lingua (2019), 16(2): 157-174. Http://doi.org/10.30957/lingua.v16i2.265.

\begin{tabular}{|c|c|c|}
\hline 2 ho koantsa & $\begin{array}{l}\text { To mischievously peep } \\
\text { at something that one } \\
\text { is not supposed to see } \\
\text { and usually getting } \\
\text { away with it }\end{array}$ & $\begin{array}{l}\text { To cheat during a test or an examination from a } \\
\text { piece of paper well-prepared prior to writing a test } \\
\text { or an exam. The students bring to exam halls well- } \\
\text { prepared papers filled with information to copy from } \\
\text { during the exam. The practice is that such forbidden } \\
\text { material they call their references would be consulted } \\
\text { should a need be despite the presence of the } \\
\text { invigilator. Students usually marvel at their cunning } \\
\text { conduct of getting away with their cheating }\end{array}$ \\
\hline 3 ho popa & To win at first draw & $\begin{array}{l}\text { To get a benefit that puts one at an advantage over } \\
\text { others such as getting a date or getting students } \\
\text { allowance from National Manpower Development } \\
\text { Secretariat. The students use the expression in a } \\
\text { context where a senior student proposes a first year } \\
\text { student. It is believed that a relationship of this } \\
\text { unequal status gives one an advantage over another; } \\
\text { the assumption is that the senior student did not find } \\
\text { any challenge proposing to a junior student; it was an } \\
\text { easy catch. The same expression is used when } \\
\text { students get monthly allowance from the government. } \\
\text { For them, it is sheer luck to get the government } \\
\text { allowance since not all students are sponsored by the } \\
\text { government and the students do not seem to know or } \\
\text { understand the criteria used to select those who are } \\
\text { sponsored. }\end{array}$ \\
\hline 4 ho ja lehlakana & To eat a plant & $\begin{array}{l}\text { To smoke. The difference in the senses here is marked } \\
\text { on the use of the polysemous verbs 'eat' and 'smoke'. } \\
\text { The intention of the students to use eat instead of } \\
\text { smoke to refer to one action is to confuse the } \\
\text { listener/receiver/audience as to what exactly is the } \\
\text { speaker going to do. Students disclosed that since } \\
\text { smoking is not an accepted action for youngsters, the } \\
\text { expression is usually used to hide the real meaning } \\
\text { from somebody whom they fear or respect such as a } \\
\text { lecturer or an elderly person whom they would not } \\
\text { want to see them smoking. }\end{array}$ \\
\hline 5 ho chesa & To burn & $\begin{array}{l}\text { To out-perform others in class. This term is used to } \\
\text { refer to students who top others in class. Such students } \\
\text { are considered untouchable, unmatchable; they cannot } \\
\text { be touched as one cannot touch a hot object at lest one } \\
\text { gets burned. The term burn is polysemous in that it } \\
\text { denotatively refers to burning or being hot while at the } \\
\text { same time students use it to refer to a person whose } \\
\text { performance is outstanding academically and is not } \\
\text { competed with. }\end{array}$ \\
\hline
\end{tabular}


LINGUA, Vol. 16, No. 2, September 2019

p ISSN: 1979 9411; e ISSN: 2442 238X

Http://lingua.soloclcs.org; Email: presslingua@gmail.com

Center of Language and Cultural Studies, Surakarta, Indonesia

Kolobe, 'Maboleba \& Thetso, 'Madira. 2019. Language use by tertiary students:

The case of the National University of Lesotho.

Lingua (2019), 16(2): 157-174. Http://doi.org/10.30957/lingua.v16i2.265.

Table 2: Polysemous expressions as nominals

\begin{tabular}{|c|c|c|}
\hline Expression & Home meaning & Campus meaning \\
\hline 6 setsamaea-naha & $\begin{array}{l}\text { A person who travels } \\
\text { a lot in search of a } \\
\text { better life }\end{array}$ & $\begin{array}{l}\text { Government allowance given to university } \\
\text { students who stay off campus. Students who stay } \\
\text { off campus regard themselves unfortunate since they } \\
\text { have to cater for all their needs including paying for } \\
\text { rent and cooking for themselves contrary to their } \\
\text { fellow students who stay on students' halls of } \\
\text { residence on campus. The latter are believed to have } \\
\text { a 'middle man' who does everything for them. For } \\
\text { instance, their rent would be paid for them hence } \\
\text { they do not need to know when it is paid and how } \\
\text { much is paid because that is between the university } \\
\text { and the government. On the contrary, those who } \\
\text { reside off campus have to do those themselves. Even } \\
\text { for other chores such as washing and cleaning, if } \\
\text { they cannot do those themselves, they have to } \\
\text { employ people who would perform such chores for } \\
\text { them. It is a common practice at the national } \\
\text { University of Lesotho that these off campus students } \\
\text { would pay 'bo-mokhotsi' (elderly people that they } \\
\text { refer to as 'friends')with the money they get from the } \\
\text { government to perform these tasks for them. The } \\
\text { money is basically referred to as a traveller because } \\
\text { the students claim they have worked hard for it to } \\
\text { find their own helpers unlike their counterparts who } \\
\text { reside on campus who do not have to shoulder all } \\
\text { this responsibility. That is, even though they also get } \\
\text { the allowance from the government, they feel that } \\
\text { they have earned it since they have to cook, wash, } \\
\text { and pay rent themselves. It is worth mentioning that } \\
\text { off campus students might as well live 'comfortably' } \\
\text { as their fellow students who reside on campus if they } \\
\text { choose to do so because they get the same amount of } \\
\text { money. }\end{array}$ \\
\hline 7 Roma boys & $\begin{array}{l}\text { Boys who live in } \\
\text { Roma }\end{array}$ & $\begin{array}{l}\text { This expression has two campus meanings. It is first } \\
\text { used to refer to people who live in Roma and are } \\
\text { stealing from university students. In many } \\
\text { occasions, these happen to be young men who stay in } \\
\text { the villages of Roma valley. Its use has also extended } \\
\text { to mean black ants that students usually find in } \\
\text { their pots which would be having food. The term is } \\
\text { therefore polysemous in that it does not only refer to } \\
\text { villagers in the Roma valley but has also extended to } \\
\text { these thieves who steal from university students. } \\
\text { Moreover, it is used to refer to the destructive insects } \\
\text { found on students' food. }\end{array}$ \\
\hline 8ntja & Dog & $\begin{array}{l}\text { A person who is famous, whether for good or bad } \\
\text { intent. The term is polysemous in that literally, it } \\
\text { refers to a domestic animal that can be good and/or } \\
\text { dangerous at times. In this context, the same term is } \\
\text { used to refer to a human being who is famous for }\end{array}$ \\
\hline
\end{tabular}


LINGUA, Vol. 16, No. 2, September 2019

p ISSN: 1979 9411; e ISSN: 2442 238X

Http://lingua.soloclcs.org; Email: presslingua@gmail.com

Center of Language and Cultural Studies, Surakarta, Indonesia

Kolobe, 'Maboleba \& Thetso, 'Madira. 2019. Language use by tertiary students:

The case of the National University of Lesotho.

Lingua (2019), 16(2): 157-174. Http://doi.org/10.30957/lingua.v16i2.265.

\begin{tabular}{|c|c|c|}
\hline & & $\begin{array}{l}\text { doing good things or notorious for bad behaviour. It } \\
\text { is interesting to note that the same term has } \\
\text { extended campus meaning to refer to a 'friend'. } \\
\text { This second campus meaning relates to the home } \\
\text { meaning if considered that dogs are usually kept as } \\
\text { pets, therefore, friends to their owners. }\end{array}$ \\
\hline $\begin{array}{l}\text { 9 } \\
\text { lehoaraho } \\
\text { ara }\end{array}$ & recycled lees & $\begin{array}{l}\text { A very skinny person. The term is used negatively } \\
\text { on campus to refer to HIV/AIDS affected persons } \\
\text { who are believed to have deteriorated because of the } \\
\text { sickness to a point where they are undermined as } \\
\text { human. }\end{array}$ \\
\hline $\begin{array}{l}\text { lo } \\
\text { sek'hoehl } \\
a\end{array}$ & rain coat & $\begin{array}{l}\text { Condom. As a raincoat is used to protect one from } \\
\text { rain,on campus, a condom is referred to a raincoat } \\
\text { because it protects one against sexually transmitted } \\
\text { diseases. }\end{array}$ \\
\hline 11sehlahla & Plant & $\begin{array}{l}\text { Voluminous hairstyle. On campus, the term is used } \\
\text { to refer to students' hair that is huge in } \\
\text { appearance/style. Its appearance is said to resemble } \\
\text { that of a plant. }\end{array}$ \\
\hline 12 palema & Flowering shrub & $\begin{array}{l}\text { Students' strike. When students on campus are on } \\
\text { strike, they cut trees and shrubs and hide behind } \\
\text { them as they sing so that they cannot easily be } \\
\text { identified. That appearance of students walking and } \\
\text { singing behind those tree leaves and scrubs has the } \\
\text { term palema extended to mean strike. }\end{array}$ \\
\hline 13lelomolo & Culture/norm & $\begin{array}{l}\text { Teenage pregnancy. The term is motivated by the } \\
\text { observation that the rate of pregnancy accelerates } \\
\text { every year on campus, it is not regarded as a } \\
\text { misfortune as Basotho culture would predict if an } \\
\text { unmarried girl falls pregnant. On campus, teenage } \\
\text { pregnancy is so high that it has turned out to be a } \\
\text { welcome practice that everybody is aware of and } \\
\text { has accepted as part of life at varsity. }\end{array}$ \\
\hline 14Kardashians & $\begin{array}{l}\text { Originally known as } \\
\text { a movie or film } \\
\text { staged in the United } \\
\text { States }\end{array}$ & $\begin{array}{l}\text { Girls with curviest body. The term is used to refer } \\
\text { to girls who are seen to have well shaped bodies. } \\
\text { This means besides the term being used to refer } \\
\text { particularly to that movie in the United States, on } \\
\text { campus, it is used to refer to people because of their } \\
\text { shape. }\end{array}$ \\
\hline
\end{tabular}

\subsection{Homonymy}

Data reveal instances of homonymy. Some expressions have acquired new meaning (campus meaning) with no apparent relationship to the literal meaning home meaning). It is not easy to draw how the home meaning influenced the campus meaning since in each context, the expression means something totally different.

Homonymy is the state or quality of a given word having the same spelling and the same sound or pronunciation as another word but with a different meaning. This is an aspect of language where words of one and the same language which are identical phonetically or graphically in all or several grammar forms have essential difference in lexical or grammatical meanings (Hurford et al., 2007). In the process of 
LINGUA, Vol. 16, No. 2, September 2019

p ISSN: 1979 9411; e ISSN: 2442 238X

Http://lingua.soloclcs.org; Email: presslingua@gmail.com

Center of Language and Cultural Studies, Surakarta, Indonesia

Kolobe, 'Maboleba \& Thetso, 'Madira. 2019. Language use by tertiary students:

The case of the National University of Lesotho.

Lingua (2019), 16(2): 157-174. Http://doi.org/10.30957/lingua.v16i2.265.

communication, the authors submit that homonyms are more of an impediment that leads to confusion and misunderstanding. There are two types of homonymy namely homographs and homophones. Homographs are polysemous words which have the same spelling but bear a different meaning. In other words, homonymy is a conceptual word that embraces both homographs and homophones. Of the collected data, there are obvious instances of homographs.

Table 3: Homonymy

\begin{tabular}{|c|c|c|}
\hline Expression & Home meaning & Campus meaning \\
\hline 15 ho sakha & To cut with a saw & $\begin{array}{l}\text { A situation when a student has deliberately } \\
\text { missed or dodged lectures. The word sakha here } \\
\text { has extended its meaning from cutting to stopping } \\
\text { the normal attendance of classes as expected. In } \\
\text { essence, the students cut the routine of going for } \\
\text { lectures. }\end{array}$ \\
\hline 16ho pheha reference & To cook reference & $\begin{array}{l}\text { To cheat about a source one has used to gather } \\
\text { information for academic writing. This } \\
\text { expression is used when a student has lied about } \\
\text { the reference used in their assignments. They } \\
\text { either provide false bibliographic details or claim } \\
\text { they have consulted certain sources when they } \\
\text { have not. The students even copy and paste their } \\
\text { colleagues' list of sources into their assignments } \\
\text { without having consulted such sources. The } \\
\text { expression is homonymous since it is difficult to } \\
\text { relate the two meanings of cooking and lying } \\
\text { about a reference. }\end{array}$ \\
\hline 17 Li mophehile & $\begin{array}{l}\text { They have cooked } \\
\text { her/him }\end{array}$ & $\begin{array}{l}\text { S/he has failed. This expression is used when a } \\
\text { student has failed an assessment task. Again the } \\
\text { relationship between cooking and failing as } \\
\text { meanings of the same expression is difficult to } \\
\text { establish. }\end{array}$ \\
\hline 18 ho lahlamollo & To scatter fire & $\begin{array}{l}\text { To show unacceptable behaviour. On campus, } \\
\text { when somebody behaves in an unacceptable } \\
\text { manner is said to 'scatter fire' The relationship } \\
\text { between these two instances is not clear. }\end{array}$ \\
\hline 19 ho ithunya & To shoot oneself & $\begin{array}{l}\text { To embarrass oneself purposely. The expression } \\
\text { is homonymous in that it is not clear how shooting } \\
\text { oneself relates to deliberately embarrassing } \\
\text { oneself. }\end{array}$ \\
\hline 20 ho ema metsing & To stand in water & $\begin{array}{l}\text { To take alcoholic drinks. The expression means } \\
\text { two things that are totally different, hence it is } \\
\text { considered homonymous. Thus, there is no } \\
\text { apparent relationship between standing in the } \\
\text { water and drinking alcohol. }\end{array}$ \\
\hline
\end{tabular}


LINGUA, Vol. 16, No. 2, September 2019

p ISSN: 1979 9411; e ISSN: 2442 238X

Http://lingua.soloclcs.org; Email: presslingua@gmail.com

Center of Language and Cultural Studies, Surakarta, Indonesia

Kolobe, 'Maboleba \& Thetso, 'Madira. 2019. Language use by tertiary students:

The case of the National University of Lesotho.

Lingua (2019), 16(2): 157-174. Http://doi.org/10.30957/lingua.v16i2.265.

\subsection{Coinage}

Coinage or neologism is a word formation process in which a new word is created deliberately or accidentally (Katamba, 1993). Data also showed few and yet significant examples of coinage as presented below.

21 mopenyo-a sexual partner with no strings attached.

22 setsoali- parent(s), parenthood

The expressions 'mopenyo' and 'setsoali' do not exist in either Sesotho or English languages which qualifies them as coined words though they might be related to Sesotho because of their Sesotho bound roots 'penya' and 'tsoali'. Mopenyo may be regarded as a derivative of the verb 'penya' (squeeze)while setsoali is derived from a noun motsoali (parent). In the context in which setsoali is used on campus, it does not fall under the same class of nouns, denoting person, as motsoali does because of the non-personification prefix /se-/ attached to it. This prefix denotes an object, hence it fits under coinage. Mopenyo on the other hand, falls under coinage also because of its internal structure. Students use the term to refer to a partner with whom they have a sexual relationship. It is formed from the existing verb penya (squeeze) but students personified it by attaching a suffix /mo-/ hence it becomes a new word in Sesotho language.

\subsection{Code-mixing instances}

Data also feature instances of code-switching. Crystal (1987) and Romaine (1992) define code-switching as the use of more than one language, variety or style by a speaker within an utterance or a discourse or between different interlocutors or situations. Based on these definitions, code-switching is regarded as a product of bilingualism or multilingualism whereby a person who has acquired more than one language shifts between them in their conversation because when languages are in contact, they influence one another. Over decades, use of language, has established that employment of code-switching is not only a habit of bilinguals but a healthy and a useful communication tool (Thompson, 2011). The tool is commonly associated with spontaneous speech as is the nature of the present study.

Of the many reasons for code-switching stipulated by Crystal (1987), only two seem relevant for this study. Data revealed that participants code-switch to convey their attitude on the listener or on the matter under question. But mainly, code-switching in this study has been used to keep 'outsiders' blank of the contents of the interaction.

Code-switching takes different forms. Poplack (1981) outlines them as tagswitching whereby a tag in included in the utterance. For example Ke ne ke lebetse $\mathrm{ka}$ taba eno, I mean, ke ntho e etsahalang, you know! (Sesotho and English) (I had forgotten about that, I mean, it happens, you know.) The English expression I mean is tagged inside the utterance, which makes it part of that utterance even though it is expressed in a different language. This kind of switching does not involve a great command of both languages. It does not violate any grammar rule. It is more of gap filler. Another type is intersentential switching. This involves switching at the phrase or sentence level. It takes place between sentences or at the boundaries of sentences; 
LINGUA, Vol. 16, No. 2, September 2019

p ISSN: 1979 9411; e ISSN: 2442 238X

Http://lingua.soloclcs.org; Email: presslingua@gmail.com

Center of Language and Cultural Studies, Surakarta, Indonesia

Kolobe, 'Maboleba \& Thetso, 'Madira. 2019. Language use by tertiary students:

The case of the National University of Lesotho.

Lingua (2019), 16(2): 157-174. Http://doi.org/10.30957/lingua.v16i2.265.

hence, it is also referred to as extra-sentential switching. For instance, 'Na ke khathetse I want to sleep (Sesotho and English). (I am tired I want to sleep). Poplack also talks of intrasentential switching whereby switching is within the sentence. This type of switching requires a great knowledge of grammars of both languages. It is rulegoverned and logical because the code-switch should not violate grammar rules of the other language. For example, I don't know why batho ba sa batle to do the right thing (Sesotho and English). (I don't know why people do not want to do the right thing.) The switch is part of the sentence and it contributes to the semantics of the sentence. Only two languages have seemingly been used in this study, Sesotho and English. This would be expected considered the language situation in Lesotho that only these two languages are given official statuses; therefore, language users would comfortably code-switch between them.

Data show intrasentential switching whereby instances of English words are fitted so well within sentences spoken in Sesotho language. All the instances of codeswitching have all observed grammar rules. For instance, the English word formatted in 23 below is expressed in the correct tense that fits the structure of the sentence to convey the state the speaker experienced. Table 4 reflects instances of code-switching.

Table 4: Code switching instances

\begin{tabular}{|l|l|l|}
\hline Expression & Home meaning & Campus meaning \\
\hline 23Keformatted & $\begin{array}{l}\text { The word formatted means } \\
\text { to organize a disc for data } \\
\text { storage }\end{array}$ & $\begin{array}{l}\text { I have totally forgotten. Students use this } \\
\text { expression to refer to a situation which they } \\
\text { would have not prepared well for an assessment } \\
\text { exercise, be it a quiz, a test or an examination. }\end{array}$ \\
\hline $\begin{array}{l}\text { 24Podium e ea } \\
\text { mbuza }\end{array}$ & $\begin{array}{l}\text { I am about to graduate. The expression is used } \\
\text { (used as when calling and } \\
\text { cutting a call before the call } \\
\text { is received on the other } \\
\text { line) } \\
\text { that as they are about to complete their studies, } \\
\text { they will soon be on the podium to have their } \\
\text { degrees conferred on them. It is also worth noting } \\
\text { that the expression has been personified as } \\
\text { podium is equated to a person who performs the } \\
\text { action of calling one on the phone. }\end{array}$ \\
\hline $25 K$ ja course & I am eating course. & $\begin{array}{l}\text { I am committed in my studies. The expression is } \\
\text { used to refer to a situation when a student is } \\
\text { seriously committed in their studies. }\end{array}$ \\
\hline $26 K$ ea servicing & I am going for a service & $\begin{array}{l}\text { I am going to drink alcohol. Instead of saying it } \\
\text { outright that one is going to take alcoholic drinks, } \\
\text { students would say they are attending a service. } \\
\text { The expression is so confusing that one would } \\
\text { even think there is a church or funeral service } \\
\text { somewhere near b). }\end{array}$ \\
\hline $27 K e$ taea ka net & $\begin{array}{l}\text { I am using information plagiarized from the } \\
\text { internet. When students have plagiarized, they } \\
\text { internet } \\
\text { true meaning of their content. }\end{array}$ \\
\hline
\end{tabular}


LINGUA, Vol. 16, No. 2, September 2019

p ISSN: 1979 9411; e ISSN: 2442 238X

Http://lingua.soloclcs.org; Email: presslingua@gmail.com

Center of Language and Cultural Studies, Surakarta, Indonesia

Kolobe, 'Maboleba \& Thetso, 'Madira. 2019. Language use by tertiary students:

The case of the National University of Lesotho.

Lingua (2019), 16(2): 157-174. Http://doi.org/10.30957/lingua.v16i2.265.

\subsection{Re-naming expressions}

Data show renamed expressions as presented below.

28Abuti Maseru (Brother Maseru)-The expression is used to refer to boys or men who come to Roma (a place where the University is situated) in flashy cars to court female students. These people hang around the campus on weekends or holidays. It is observed that the expression overgeneralizes all visitors of this nature not necessarily because they come from Maseru, capital city of Lesotho. The re-naming of the town is likely due to the town being the capital city. Therefore, the wooers are renamed after a place associated with fame and money.

29Modesk - Sesotho affix /mo/ is attached to a noun desk to refer to officer(s) working on campus at the students' halls of residence. Since their task involves guarding students from mischief such as playing loud music that disturbs others, students are not very happy to have them around; therefore, they gain self-satisfaction in mocking them by renaming them after their act of sitting on the desk to keep an eye on them. The students' motive is to derail these officers from doing their job. This is a situation of ego gratification which is explained by Steinberg (2007:26) as 'a feeling that "I am ok" ,, what I am doing is right' while in actually fact it is the opposite.

\subsection{Miscellaneous}

Data further indicate words that are used purposely to shut other people out. A popular expression in this study is ho kola mosi literally meaning to 'catch smoke'. The word's acquired meaning on campus is to be 'ignorant of what is going on'. It is used on occasions where communicators do not want 'outsiders' to participate in their interaction. In such cases, they purposely state that Re mo kolisa mosi or $O$ ne a kola mosi 'we are making him/her to catch smoke; or she/he was catching smoke' respectively. The use of language around the campus also reflects creativity. For instance, students use the word, manpower, to refer to the allowance that students get monthly from the government. Influenced by that use of the word, the students have formed a compound word boy-power to refer to the money that students on study leave get. This money is referred to as such because students feel that it is little compared to the allowance that is given to all those students sponsored by the government; therefore, the money is now under-rated equated to a boy, not a man. They have further formed a compound word parent-power to refer to the money that students who are not sponsored by the government get from their parents.

\section{CONCLUSION}

Data reflected colloquial and diverse use of well- established words in English and Sesotho. They showed that words that are literally known to have certain meanings may simply be used to mean something else in the oddest context such as those shown by University students. Data affirmed Greene \& Burleson's (2008:291) proposition that communication may be used for 'good or ill'.

The general observation evoked by these data is that university students at the National University of Lesotho display the richness of language and its wide context. 
LINGUA, Vol. 16, No. 2, September 2019

p ISSN: 1979 9411; e ISSN: 2442 238X

Http://lingua.soloclcs.org; Email: presslingua@gmail.com

Center of Language and Cultural Studies, Surakarta, Indonesia

Kolobe, 'Maboleba \& Thetso, 'Madira. 2019. Language use by tertiary students:

The case of the National University of Lesotho.

Lingua (2019), 16(2): 157-174. Http://doi.org/10.30957/lingua.v16i2.265.

At the same time, the ability to use language to suit one's goal reflects communicative competence as detailed in the earlier sections of this study.

This study has contributed a new and yet an interesting intellectual dimension of interpersonal communication which addresses specified intellectual studentship. The study has further opened a research call to explore the attitudinal behaviour of nonnative speakers towards the use of this university communication bearing in mind that usually universities are places of multilingualism.

\section{REFERENCES}

Adler, R. B., Rosenfeld, L. B. \& Proctor, R. F. (2010). Interplay: The Process of Interpersonal Communication. New York: Oxford University Press.

Altheide, D. (1996). Qualitative Media Analysis. Thousand Oaks, CA: Sage.

Braaten, J. (1991). Habermas' critical Theory of Society. Albany: State University of New York.

Cannon-Bowers, J. A., Salas, E. \& Converse, S. (1993). Shared mental models in expert team decision making. In N. J. Castellan Jr. (Ed.).Individual and Groups Decision Making: Current Issues. Hillsdale, NJ: Lawrence Erlbaum,pp.221-246.

Chan, Z. Y. (2017). A Qualitative study on communication between nursing students and the family members of patients. Nurse Education Today, 59,33-37. www.elsevier.com/locate/nedt.2/20/2018.

Clark, H. H. (1996). Using Language. Cambridge: Cambridge University Press.

Cleary, S.( Ed.). (1999). The Communication Handbook. Cape Town: Juta and Co. Ltd.

Crabtree, F. B. \& Miller. M. L. (1992). Doing Qualitative Research, Part 657. Sage University: Sage Publications.

Crystal, D. (1987). The Cambridge Encyclopedia of Language. Cambridge: Cambridge University Press.

Evans, V. \& Zinken, J. (2006). Figurative language in a modern theory of meaning construction: A lexical concepts and cognitive models approach.(N.P.)

Falkum, I. L. (2011). The semantics and pragmatics of polysemy: A relevancetheoretical account. A doctoral thesis. University College London. [discovery.ucl.ac.uk/1139079/1/1139079.pdf]. Accessed 2/23/2018.

Fillmore, C. J. \&Atkins, B. T. (2000).Describing polysemy: The case of 'crawl'. In Ravin, V, \& C, Leacock. Polysemy: Theoretical and Computational Approaches. Oxford: Oxford University Press.

Gillham, B. (2000). Case Study Research Methods. Bloomsbury: Bloomsbury Academic.

Goldfinch, J. \& Hughes, M. (2007).Skills, learning styles and success. Active Learning in Higher Education, 8(3).

Greene, J. O. and Burleson, B. R. (Eds). (2008). Handbook of Communication and Social Interaction Skills. New Jersey: Taylor \& Francis e-Library.

Harvey, P. \&Ahmann, E. (2016). Validation: a family-centred communication skill. Nephrol. Nurse Journal, 43(1), 61-66. 
LINGUA, Vol. 16, No. 2, September 2019

p ISSN: 1979 9411; e ISSN: 2442 238X

Http://lingua.soloclcs.org; Email: presslingua@gmail.com

Center of Language and Cultural Studies, Surakarta, Indonesia

Kolobe, 'Maboleba \& Thetso, 'Madira. 2019. Language use by tertiary students:

The case of the National University of Lesotho.

Lingua (2019), 16(2): 157-174. Http://doi.org/10.30957/lingua.v16i2.265.

Hsieh, H. \& Shannon, S. E. (2005). 'Three approaches to qualitative content analysis'.<journals.sagepub.com/doi/abs/10.1177/1049732305276687?journalCo $\mathrm{de}=$ ghra $>$.

Huebsch, J. C. (1995). Communication Skills. Pretoria: Kagiso Publishers.

Hurford, J., Heasley, B. \& Smith, M. (2007). Semantics: A Coursebook. (2 ${ }^{\text {nd }}$ ed.). Cambridge: Cambridge University Press.

https://hbswk.hbs.edu/item/componential-theory-of-creativity

Hymes, D. H. (1993). Inequality in language: Taking for granted. In J. E. Alatis (Ed.). Language, communication and social meaning. 23-40. Washington, D.C.: Georgetown University Press.

Johnson, K. \& Johnson, H. (1998). Communicative competence. Encyclopedic dictionary of applied linguistics, 62-67. Oxford: Blackwell.

Katamba, F. (1993).Morphology. London: Macmillan Press Limited.

King, K., Porr, C. \& Gaudine, A. (2017). Fostering academic success among English as an additional language nursing students using standardized patients. Clinical Simulation in Nursing, 13 (10), 524-530.

Mahmud, M. M. (2014). Communication aptitude and academic success. Journal of Procedia Social and Behavioural Sciences, 13(4), 125-133.

McCroskey, J. C., Booth-Butterfield, S. \& Payne, S.K. (1989). Impact of communication apprehension. Communication Quarterly.

Meyer, C. B. (2001).A Case in case study methodology. Field Methods, 13(4),329-352. [jashotta.tripod.com/case.pdf].

Mkanganwi, K. G. (1987). Linguistics, language and Zimbabwe. Proceedings of the second linguistics association for SADCC universities conference, held at the University of Zimbabwe, 2-5 September.

Nerlich, B. (2003). Polysemy: past and present. In Polysemy: Flexible Patterns of Meaning in Mind and Language. Nerlich, Z., Todd, V., Herman, D. \& Clarke, D. 49-76. Berlin: Moiuton de Gruyter.

O’Grady, W.D., Dobrovolsky, M. \& Katamba, F. (1996).Contemporary Linguistics: An Introduction. California: Longman.

Pearson, J. C., Nelson P. E., Titsworth, S. \& Harter, C.(2003). Human communication. Boston: McGraw Hill.

Romaine, S. (1992). Language, education and development. Oxford: Clarendon Press.

Roze Des Ordons, A. L., Doig, C. L., Couillard, P. \& Lord, J. (2017). From communication skills to skillful communication: A longitudinal integrated curriculum for critical care medicine fellows. Academic Medicine, 92(4), 501505.

Samovar, L. \& Porter, R. (2001). Communication and Cultures. Wadsworth; Thompson Learning.

Sandelowski, M. (2010).What's in a name? Qualitative description revisited. Res. Nurse Health, 33, 77-84.

Stake, R. (1995). The Art of Case Study Research. 1000 Oak: Sage Publication. 
LINGUA, Vol. 16, No. 2, September 2019

p ISSN: 1979 9411; e ISSN: 2442 238X

Http://lingua.soloclcs.org; Email: presslingua@gmail.com

Center of Language and Cultural Studies, Surakarta, Indonesia

Kolobe, 'Maboleba \& Thetso, 'Madira. 2019. Language use by tertiary students:

The case of the National University of Lesotho.

Lingua (2019), 16(2): 157-174. Http://doi.org/10.30957/lingua.v16i2.265.

Steinberg, T. (2000). An Introduction to Communication Studies. Cape Town: Juta and Co. Ltd.

Taylor, J. R. (2006). Polysemy and the lexicon. In Cognitive Linguistics: Current Applications and Future Perspectives. Achard, K. G., Dirven, R. \&Ruizde, M. I. (Eds.) 51-80.

Thompson, N. (2011). Effective Communication: A Guide for the People professions. ( $2^{\text {nd }}$ ed.) New York: Palgrave Macmillan.

Wiemann, J. M. (1997). Explication and test of a model of communicative competence. Journal of Human Communication Research, 3, 195-213.

Yahaya, A. \& Ramli, J. (2009). The relationship between self-concept and communication skills towards academic achievement among secondary School students in Johor Bahru.<www.ccsenet.org/journal.html $>$.

Yin, K. R. (2009). Case study research design and methods. London: Sage Publication.

Zimmerman, B. J. (2000). Self-efficacy: An essential motive to learn. Contemporary Education Psychology, 25(1), 82-91. 